\title{
Cloning and characterization of resistance gene analogs from under- exploited plant species
}

\author{
Ramasubramanian Thirumalaiandi \\ Division of Crop Protection \\ Central Research Institute for Jute and Allied Fibres \\ Indian Council of Agricultural Research \\ Barrackpore, Kolkata, 700 120, India \\ Tel: 91332535 6121/6122. Ext. 220 \\ Fax: 913325350415 \\ E-mail: tramasubbu@rediffmail.com \\ Michael Gomez Selvaraj \\ Department of Plant and Soil Science \\ Texas Tech University \\ Texas, USA \\ Tel: 8067466101 \\ Fax: 8067466528 \\ E-mail: mselvaraj@ag.tamu.edu \\ Raghu Rajasekaran \\ Dipartimento di Scienze del Mare \\ Università Politecnica delle Marche \\ 60131 Ancona, Italy \\ Tel: 390712204659 \\ Fax: 39712204650 \\ E-mail:raghurajasekaran@gmail.com \\ Mohankumar Subbarayalu* ${ }^{*}$ \\ Department of Plant Molecular Biology and Biotechnology \\ Centre for Plant Molecular Biology \\ Tamil Nadu Agricultural University \\ Coimbatore, 641 003, Tamil Nadu, India \\ Fax: 91-4222431672 \\ E-mail: smohankumar65@yahoo.com
}

Keywords: Adenanthera pavonina, Clitoria ternatea, NBS-LRR, Pongamia glabra, resistance gene analogs, solanum trilobatum.

Present addresses: \#Agricultural Research Station, Vaigaidam, Tel: 91-4546244112.

Abbreviations: RGAs: resistance gene analogs

$R$-genes: resistance genes

Genomic DNA sequences sharing homology with NBS region of resistance gene analogs were isolated and characterized from Pongamia glabra, Adenanthera pavonina, Clitoria ternatea and Solanum trilobatum using PCR based approach with primers designed from conserved regions of NBS domain. The presence of consensus motifs viz., kinase 1a, kinase 2 , kinase $3 a$ and hydrophobic domain provided evidence that the cloned sequences may belong to the NBS-LRR gene family. Conservation of tryptophan as the last residue of kinase-2 motif further confirms their position in nonTIR NBS-LRR family of resistance genes. The Resistance Gene Analogs (RGAs) cloned from P. glabra, A. pavonina, C. ternatea and S. trilobatum clustered together with well- characterized non -TIR-NBS-LRR genes leaving the TIR-NBS-LRR genes as a separate cluster in the average distance tree constructed based on BLOSUM62. All the four RGAs had high level of identity with NBS-LRR family of RGAs deposited in the GenBank. The extent of identity between the sequences at NBS region varied from $29 \%$ ( $P$. glabra and $S$. trilobatum) to $78 \%$ (A. pavonina and C. ternatea), which indicates the diversity among the RGAs.

Plant disease resistance genes ( $R$-genes) have been cloned and characterized from both mono- and dicotyledonous plants (Hammond-Kosack and Jones, 1997). More than 50 $R$-genes have been cloned so far from a variety of plant species (Wenkai et al. 2006). Among them, 37 share the NBS-LRR domain in their protein sequences and form the

*Corresponding author 
Table 1. Results of BL2SEQ Algorithm showing the extent of identity between the RGAs isolated in the present investigation and their comparison with representatives of NBS-LRR class $R$-genes.

\begin{tabular}{|c|c|c|c|c|c|c|c|c|c|}
\hline & P. glabra & A. pavonina & C. ternatea & S. trilobatum & $N$ & RPS2 & $X A 1$ & RPS5 & RPP8 \\
\hline P. glabra & $\begin{array}{c}100 \\
\left(1 e^{-96}\right)\end{array}$ & $\begin{array}{c}54 \\
\left(1 \mathrm{e}^{-08}\right)\end{array}$ & $\begin{array}{c}32 \\
\left(3 e^{-11}\right)\end{array}$ & $\begin{array}{c}29 \\
\left(1 \mathrm{e}^{-12}\right)\end{array}$ & $\begin{array}{c}27 \\
\left(3 e^{-11}\right)\end{array}$ & $\begin{array}{c}29 \\
\left(3 \mathrm{e}^{-13}\right)\end{array}$ & $\begin{array}{c}36 \\
\left(8 \mathrm{e}^{-26}\right)\end{array}$ & $\begin{array}{c}28 \\
\left(4 \mathrm{e}^{-11}\right)\end{array}$ & $\begin{array}{c}30 \\
\left(2 \mathrm{e}^{-11}\right)\end{array}$ \\
\hline A. pavonina & & $\begin{array}{c}100 \\
\left(2 e^{-92}\right)\end{array}$ & $\begin{array}{c}78 \\
\left(3 e^{-67}\right)\end{array}$ & $\begin{array}{c}34 \\
\left(2 \mathrm{e}^{-15}\right)\end{array}$ & $\begin{array}{c}25 \\
(0.007)\end{array}$ & $\begin{array}{c}32 \\
\left(7 e^{-13}\right)\end{array}$ & $\begin{array}{c}29 \\
\left(2 \mathrm{e}^{-06}\right)\end{array}$ & $\begin{array}{c}32 \\
\left(1 \mathrm{e}^{-14}\right)\end{array}$ & $\begin{array}{c}26 \\
\left(1 \mathrm{e}^{-05}\right)\end{array}$ \\
\hline C. ternatea & & & $\begin{array}{c}100 \\
\left(1 e^{-92}\right)\end{array}$ & $\begin{array}{c}32 \\
\left(1 \mathrm{e}^{-12}\right)\end{array}$ & $\begin{array}{c}25 \\
(0.016)\end{array}$ & $\begin{array}{c}32 \\
\left(2 \mathrm{e}^{-08}\right)\end{array}$ & $\begin{array}{c}26 \\
\left(6 \mathrm{e}^{-04}\right)\end{array}$ & $\begin{array}{c}30 \\
\left(1 \mathrm{e}^{-10}\right)\end{array}$ & $\begin{array}{c}27 \\
\left(3 e^{-06}\right)\end{array}$ \\
\hline S. trilobatum & & & & $\begin{array}{c}100 \\
\left(3 e^{-92}\right)\end{array}$ & $\begin{array}{c}25 \\
(0.087)\end{array}$ & $\begin{array}{c}41 \\
\left(3 e^{-30}\right)\end{array}$ & $\begin{array}{c}28 \\
\left(1 e^{-11}\right)\end{array}$ & $\begin{array}{c}47 \\
\left(3 e^{-33}\right)\end{array}$ & $\begin{array}{c}29 \\
\left(9 e^{-09}\right)\end{array}$ \\
\hline$N$ & & & & & $\begin{array}{c}100 \\
\left(2 \mathrm{e}^{-94}\right)\end{array}$ & $\begin{array}{c}25 \\
(0.057)\end{array}$ & $\begin{array}{c}25 \\
\left(9 \mathrm{e}^{-05}\right)\end{array}$ & $\begin{array}{c}26 \\
(0.48)\end{array}$ & $\begin{array}{c}25 \\
(0.078)\end{array}$ \\
\hline RPS2 & & & & & & $\begin{array}{c}100 \\
\left(1 \mathrm{e}^{-93}\right)\end{array}$ & $\begin{array}{c}29 \\
\left(4 \mathrm{e}^{-10}\right)\end{array}$ & $\begin{array}{c}45 \\
\left(9 e^{-35}\right)\end{array}$ & $\begin{array}{c}26 \\
\left(1 \mathrm{e}^{-07}\right)\end{array}$ \\
\hline$X A 1$ & & & & & & & $\begin{array}{c}100 \\
\left(6 \mathrm{e}^{-98}\right)\end{array}$ & $\begin{array}{c}28 \\
\left(3 e^{-08}\right)\end{array}$ & $\begin{array}{c}27 \\
\left(2 \mathrm{e}^{-09}\right)\end{array}$ \\
\hline RPS5 & & & & & & & & $\begin{array}{c}100 \\
\left(2 \mathrm{e}^{-98}\right)\end{array}$ & $\begin{array}{c}24 \\
\left(3 \mathrm{e}^{-05}\right)\end{array}$ \\
\hline RPP8 & & & & & & & & & $\begin{array}{c}100 \\
\left(4 e^{-100}\right)\end{array}$ \\
\hline
\end{tabular}

largest $R$-gene class (Bent et al. 1994; Lawrence et al. 1995; Kaloshian et al. 1998; Yoshimura et al. 1998). Genes from the NBS-LRR class confer resistance to bacteria, fungi, virus, nematodes and aphids (Timmerman-Vaughan et al. 2000). No function other than disease resistance has yet been assigned to this large class of genes (Bai et al. 2002). The NBS-LRR class resistance genes are proposed to act as receptors in signal transduction pathways that are triggered in response to pathogen attack (Hammond-Kosack and Jones, 1997). The NBS region is thought to be important for ATP binding and overall functionality of the $R$-gene product (Walker et al. 1982; Saraste et al. 1990). The NBSLRR class of $R$ genes have been cloned and well characterized from Arabidopsis thaliana, flax, tobacco, tomato and rice (Bent et al. 1994; Mindrinos et al. 1994; Whitham et al. 1994; Grant et al. 1995; Lawrence et al. 1995; Milligan et al. 1998; Yoshimura et al. 1998). The NBS region of characterized $R$-genes and $R$-gene analogs (RGAs) contains several highly conserved motifs, in spite of the diversity of pathogens against which they act. The Ploop and the kinase-2 domains have been described as ATP- and GTP- binding sites (Traut, 1994; Meyers et al. 1999). Additional motifs found in the NBS region of plant resistance genes are the kinase-3a and the GLPL (also called "hydrophobic domain"), a putative membrane spanning domain (Baldi et al. 2004). By making use of these conserved domains, NBS-sequences were obtained by PCR-mediated approach and provided candidate resistance genes (or Resistance Gene Analogs) in several crops such as potato (Leister et al. 1996), soybean (Kanazin et al. 1996; Yu et al. 1996; Peñuela et al. 2002; He et al. 2003), maize (Collins et al. 1998), sunflower (Gentzbittel et al. 1998), lettuce (Shen et al. 1998), Brassica (Joyeux et al. 1999), rice (Mago et al. 1999), common bean (Rivkin et al. 1999), citrus (Deng et al. 2000), coffee (Noir et al. 2001), chickpea (Huettel et al. 2002), grapewine (Donald et al. 2002), apple (Lee et al. 2003), wheat (Lacock et al. 2003), chicory (Plocik et al. 2004) and sorghum (Totad et al. 
2005). The RGA fragments were also used as molecular markers for tagging the disease resistance loci in Arabidopsis thaliana (Aarts et al. 1998), wheat (Chen et al. 1998), rice (Ilag et al. 2000), melon (Mas et al. 2001), cowpea (Gowda et al. 2002), Lycopersicon (Zhang et al. 2002), common bean (Lopez et al. 2003), cocoa (Lanaud et al. 2004) and cotton (Hinchliffe et al. 2005).

Pongamia glabra (synonym: Millettia pinnata; Family: Fabaceae), Adenanthera pavonina (Family: Fabaceae) and Clitoria ternatea (Family: Fabaceae) are among the few under-exploited non-edible legumes. Pongamia oil has immense potential as a synergist by suppressing the activity of detoxification enzymes in insects (Ramasubramanian and Regupathy, 2004). The seeds of A. pavonina contain thermo stable chitinases (Santos et al. 2004), which are one among the important pathogenesis related proteins. C. ternatea is resistant to a number of pests and pathogens owing to the presence of a defense protein designated as "finotin". Finotin was found to be highly toxic to insects and important fungal pathogens of plants (Kelemu et al. 2004). C. ternatea is one of the important forage legumes having ornamental value, and the potential of which is being explored now through breeding programmes (Kalamani and Michael Gomez, 2001; Kalamani and Michael Gomez, 2002; Kalamani and Michael Gomez, 2003; Michael Gomez and Kalamani, 2003). Solanum trilobatum (Family: Solanaceae) has been in use for various ailments in different parts of India (Govindan et al. 1999, Madhavan and Balu, 1999) and its active principle sobatum was reported to possess anti-tumor activity (Mohanan and Devi, 1996; Mohanan and Devi, 1997). The leaf extract of S. trilobatum was reported to possess oviposition deterrent and skin repellent activities against the mosquito Anopheles stephensi (Rajkumar and Jebanesan, 2005). The insecticidal and antimicrobial activities of these underexploited plant species insisted to look for resistance gene analogs. In this paper we described the cloning, sequencing and diversity of NBS-LRR class of RGAs from P. glabra, A. pavonina, C. ternatea, and $S$. trilobatum from which no RGAs have yet been cloned.

\section{MATERIALS AND METHODS}

\section{DNA isolation and PCR amplification}

Genomic DNA from A. pavonina, C. ternatea, P. glabra and $S$. trilobatum was extracted by adopting CTAB procedure (Doyle and Doyle, 1990) with necessary modifications. Quality and quantity of the DNA was measured in NanoDrop ${ }^{\circledR}$ ND-1000 spectrophotometer. PCR amplifications were carried out in a $100 \mu \mathrm{l}$ reaction containing $100 \mathrm{ng}$ genomic DNA, $0.2 \mu \mathrm{M}$ of each primer (designed from consensus sequences of NBS region 5'GGTGGGGTTGGGAAGACAACG-3',

$5-$ CAACGCTAGTGGCAATCC-3') (Leister et al. 1996), $0.25 \mathrm{mM}$ each of the four dNTPs (Fermentas Life Sciences, Canada), $2 \mathrm{mM} \mathrm{MgCl}$, 1 x Taq buffer (GeNei, India) and
2.5 U Taq DNA polymerase (GeNei, India). PCR was performed in MyCycler $^{\mathrm{TM}}$ thermal cycler (BioRad, USA) with initial denaturation at $94^{\circ} \mathrm{C}$ for $3 \mathrm{~min}$, then cycling for 19 times using a touch-down strategy (an initial cycle of $94^{\circ} \mathrm{C}$ for $30 \mathrm{sec}, 63^{\circ} \mathrm{C}$ for $30 \mathrm{sec}, 72^{\circ} \mathrm{C}$ for $1 \mathrm{~min}$, then lowering the annealing temperature for each cycle by $0.5^{\circ} \mathrm{C}$ during the following 18 cycles), followed by 19 cycles at $94^{\circ} \mathrm{C}$ for $15 \mathrm{sec}, 55^{\circ} \mathrm{C}$ for $30 \mathrm{sec}$ and $72^{\circ} \mathrm{C}$ for $1 \mathrm{~min}$ then final extension at $72^{\circ} \mathrm{C}$ for $10 \mathrm{~min}$. Amplified PCR products were electrophoresed in $1.5 \% \mathrm{w} / \mathrm{v}$ agarose gels (SigmaAldrich, India) stained with ethidium bromide. PCR fragments were excised under UV transilluminator (Fotodyne, USA) and purified using GenElute ${ }^{\mathrm{TM}}$ Gel Extraction Kit (Sigma Aldrich, USA).

\section{Cloning of DNA fragments}

The purified PCR fragments of P. glabra, A. pavonina, C. ternatea and $S$. trilobatum were cloned into plasmid vector pTZ57R/T using InsT/Aclone ${ }^{\mathrm{TM}}$ PCR Product Cloning Kit (Fermentas Life Sciences, Canada) and transformed into competent Escherichia coli strain $\mathrm{DH} 5 \alpha$ by following manufacturer's instructions. The transformed colonies were screened and confirmed for the presence of insert by colony PCR. Plasmid DNA was isolated by adopting the protocol described by Birnboim and Doly (1979) with necessary modifications. The presence of the insert was confirmed by double digestion of plasmid DNA with EcoRI and BamHI restriction enzymes (Fermentas Life Sciences, Canada). Sequencing of the purified plasmid was done in an automated ABI 3100 Genetic Analyser based on Sangers's sequencing method at GeNei, Bangalore, India.

\section{Diversity analysis of cloned DNA fragments using Bioinformatic tools}

The nucleotide sequences of the cloned fragments were translated in to amino acid sequences using ExPASy (Expert Protein Analysis System) Translate Tool, a proteomics server of Bioinformatics. The deduced amino acid sequences were subjected to motif analyses using the online version of CLUSTALW multiple alignment program of European Bioinformatics Institute (Thompson et al. 1997). The amino acid sequences of the RGAs were compared with protein sequences deposited in the GenBank using BLASTP algorithm (Altschul et al. 1997). Pair wise comparison of RGA sequences with known $R$-gene sequences at NBS region was made using BL2SEQ algorithm (Tatusova and Madden, 1999). In addition to these, amino acid sequences of RGAs isolated from the model legumes Glycine max (Kanazin et al. 1996), Pisum sativum (Timmerman-Vaughan et al. 2000) and Medicago truncatula (Cannon et al. 2002) were retrieved from the GenBank and were trimmed to start and end at the P-loop and GLPL motifs to facilitate accurate alignments with the sequences cloned in the present study. The Jalview Java alignment editor was used to construct average distance tree based on BLOSUM62 (Clamp et al. 2004). 
Table 2. Results of similarity searches between RGAs isolated in the present investigation and GenBank accessions using BLASTP algorithm.

\begin{tabular}{|c|c|c|c|c|}
\hline $\begin{array}{c}\text { RGA } \\
\text { (GenBank Accession } \\
\text { Numbers) }\end{array}$ & $\begin{array}{c}\text { GenBank protein accession showing } \\
\text { highest identity }\end{array}$ & $\begin{array}{l}\text { GenBank ID } \\
\text { (GI) }\end{array}$ & $\begin{array}{l}\text { Amino acid } \\
\text { identity (\%) }\end{array}$ & E value \\
\hline \multirow[t]{3}{*}{$\begin{array}{l}\text { P. glabra } \\
\text { (DQ910862) }\end{array}$} & $\begin{array}{l}\text { Putative resistance protein KNBS4 of } \\
\text { Glycine max }\end{array}$ & 13111697 & 71 & $8 e^{-62}$ \\
\hline & $\begin{array}{l}\text { NBS-LRR type disease resistance protein } \\
\text { RPG1-B of Glycine max }\end{array}$ & $\begin{array}{l}38373621 \\
38373623 \\
38373625\end{array}$ & 68 & $2 e^{-63}$ \\
\hline & $\begin{array}{l}\text { Disease resistance protein; AAA ATPase } \\
\text { of Medicago truncatula }\end{array}$ & 92885110 & 68 & $3 e^{-62}$ \\
\hline $\begin{array}{l}\text { A. pavonina } \\
\text { (DQ910859) }\end{array}$ & $\begin{array}{l}\text { NBS- type resistance protein of } \\
\text { Gossypium barbadense }\end{array}$ & 29703837 & 45 & $5 e^{-25}$ \\
\hline $\begin{array}{l}\text { C. ternatea } \\
\text { (DQ910861) }\end{array}$ & $\begin{array}{l}\text { NBS- type resistance protein of } \\
\text { Gossypium barbadense }\end{array}$ & 29703837 & 42 & $3 e^{-29}$ \\
\hline \multirow[t]{7}{*}{$\begin{array}{l}\text { S. trilobatum } \\
\text { (DQ910860) }\end{array}$} & $\begin{array}{l}\text { ATP binding protein of Arabidopsis } \\
\text { thaliana }\end{array}$ & 30696557 & 52 & $1 e^{-42}$ \\
\hline & T1F9.21 of Arabidopsis thaliana & 3056600 & 52 & $5 e^{-42}$ \\
\hline & $\begin{array}{l}\text { Putative disease resistance protein } \\
\text { At1g61300 of Arabidopsis thaliana }\end{array}$ & 46395619 & 52 & $5 e^{-42}$ \\
\hline & $\begin{array}{l}\text { NBS-LRR-Non-Toll resistance gene } \\
\text { analog protein of Medicago ruthenica }\end{array}$ & 19774147 & 52 & $5 e^{-41}$ \\
\hline & $\begin{array}{l}\text { ATP binding protein of Arabidopsis } \\
\text { thaliana }\end{array}$ & 15219879 & 51 & $5 e^{-40}$ \\
\hline & $\begin{array}{l}\text { Putative disease resistance protein } \\
\text { At1g61190 of Arabidopsis thaliana }\end{array}$ & 46395603 & 51 & $5 e^{-40}$ \\
\hline & $\begin{array}{l}\text { RPS2 disease resistance protein-like } \\
\text { protein of Arabidopsis thaliana }\end{array}$ & 2443883 & 51 & $5 e^{-40}$ \\
\hline
\end{tabular}

\section{RESULTS AND DISCUSSION}

\section{PCR amplification of targeted RGA fragment}

The discovery of conserved motifs among the NBS-LRR class resistance genes opens the avenue for the use of PCR based strategy in isolating and cloning $R$ gene family members and analogs using degenerate or specific primers. This approach thus provides an alternative to the classical methods of transposan tagging and map-based cloning strategies used so far (Seah et al. 1998). In earlier studies, co-amplification of non specific fragments apart from the expected amplicon (500-600 bp) was observed in crops like soybean (Yu et al. 1996), rice (Mago et al. 1999) and sorghum (Totad et al. 2005). Increasing the stringency of
PCR condition by adopting higher annealing temperature, "hot start" and "touch-down" protocols were not successful in obtaining the more specific fragment in Cucumis melo (Brotman et al. 2002). However, in the present study we were successful in amplifying only the targeted RGA fragment (as was expected from the distance between the sequence motifs in $N$ gene of tobacco and RPS2 of Arabidopsis thaliana) from the genomic DNA of $A$. pavonina, C. ternatea, P. glabra and S. trilobatum probably due to high stringency PCR conditions combined with touch-down strategy (Figure 1).

\section{Sequence analysis for conserved motifs}

The amino acid sequences of RGAs cloned in the present investigation were compared with other known $R$ genes 
viz., $N$ gene of tobacco, RPS2, RPS5 and RPP8 of A. thaliana, XA1 of rice and $L 6$ of flax in NBS region using CLUSTALW multiple alignment program (Figure 2). The various motifs of NBS, i.e., kinase-1a, kinase-2 and kinase3a were conserved in P. glabra, A. pavonina, C. ternatea, and $S$. trilobatum RGAs. The hydrophobic region represented by the GLPL domain was also observed in all the four RGA sequences. High sequence homology of the RGAs with NBS motifs of $N$, RPS2, RPS5, RPP8, L6 and $X A 1$ clearly establishes that the RGAs cloned in the present investigation might belong to NBS-LRR class of $R$-genes. The NBS-LRR genes are usually grouped into two different subfamilies (Meyers et al. 1999; Pan et al. 2000): subfamily I contains the TIR element (Toll-Interleukin-1 Receptorlike domain) and has been found only in dicots, while subfamily II lacks the TIR domain and has been found both in dicots and monocots. The partial sequence of the NBS portion is usually sufficient to assign a given gene to either subfamily I or II. The last residue of the kinase-2 domain can be used to predict with $95 \%$ accuracy whether an RGA would belongs to the TIR-NBS or the non-TIR-NBS family; conservation of tryptophan (W) at this location is tightly linked to non-TIR R-genes (RPS2, RPS5 and RPP8 of A. thaliana), whereas conservation of aspartic acid (D) or its uncharged derivative aspartate $(\mathrm{N})$ is characteristic of TIR class of $R$-genes ( $N$ and L6) (Meyers et al. 1999; Pan et al. 2000; Jeong et al. 2001; Peñuela et al. 2002). The conservation of tryptophan (W) in the P. glabra, A. pavonina and $S$. trilobatum RGAs with the exception of $C$. ternatea indicates that these belong to the non-TIR subfamily of NBS-LRR genes. A. pavonina clone is likely to be a pseudogene because it contains a stop codon, which might have evolved during the course of evolution. In TIRNBS-LRR group, a characteristic consensus motif FXXXXF and a highly conserved glycine is present between kinasela and kinase-2 domains, whereas the nonTIR-NBS-LRR group contains the consensus sequence FXXXXW (Pan et al. 2000). The presence of consensus motif FXXXXW between kinase 1a and kinase-2 domains of $P$. glabra and S. trilobatum RGA sequences further ensures their position in non-TIR-NBS-LRR subfamily.

Phylogenetic analysis of RGA sequences with already characterized $R$-genes was done by constructing average distance tree using BLOSUM62 in the Jalview Java alignment editor. The RGAs of P. glabra, A. pavonina, $C$. ternatea and $S$. trilobatum were clustered together with well- characterized non-TIR-NBS-LRR genes RPS2, RPS5 and $R P P 8$ of $A$. thaliana, while the TIR-NBS-LRR genes $N$ and $L$ were grouped as a separate cluster (Figure 3 ). Another average distance tree was constructed for the RGAs cloned in this study and those isolated from the model legumes Glycine, Pisum and Medicago. The RGAs were grouped in to two major clades each represents the TIR and Non-TIR NBS-LRR subfamilies of $R$ genes (Figure 4). The RGAs cloned from $P$. glabra and $S$. trilobatum showed high similarity with MedicagoD10b_Mt14 RGA and Pisum RGA 2.97, respectively. The Pisum RGA 2.97 has already been reported to share high similarity with the well-known non-TIR-NBS-LRR gene RPS2 (Kanazin et al. 1996). The RGAs isolated from A. pavonina and C. clitoria were clustered together in a single subclade and exhibit their sequence similarity.

\section{Comparison of RGAs with known $R$-genes using BL2SEQ algorithm}

The RGAs cloned in the present study were compared with representative NBS-LRR class $R$-genes viz., $N$ gene of tobacco, RPS2, RPS5 and RPP8 of A. thaliana and XA1 of rice in NBS region using BL2SEQ algorithm (Tatusova and Madden, 1999). The $R$-gene analogs showed comparable identity with Non-TIR-NBS-LRR genes and TIR-NBSLRR gene. However, all the four RGAs had lowest E values with Non-TIR-NBS-LRR genes, RPS2, RPS5, RPP8 and XA1 as against the TIR-NBS-LRR gene, $N$ (Table 1). This confirms the strong match with Non-TIR-NBS-LRR gene family. The extent of amino acid identity between the representative NBS-LRR class $R$-genes was also analysed for comparison using the BL2SEQ algorithm. The percentage of identity at NBS region between $N$ and RPS2 (25\%), $N$ and XA1 (25\%), RPS2 and XA1 (29\%) (Table 1) indicates that the homology between them was mainly restricted to the different motifs of NBS, thereby indicating sequence diversity among the NBS-LRR class resistance genes. The extent of identity between the RGAs themselves varied between $29 \%$ and $78 \%$, which reveals the diversity among the RGAs isolated in the present study.

\section{BLAST search for identical protein sequences}

It was well established that the protein level search and comparison showed more homology with NBS-LRR region of many RGAs than at the nucleotide level due to degeneracy of the genetic code. Thus, pair wise comparison at amino acid level is more reliable than nucleotidenucleotide comparison for establishing the identity of any RGA (Totad et al. 2005). Hence, the nucleotide sequences were translated in to polypeptides using ExPASy translate tool and identity search was made using BLASTP algorithm. All the four $R$-gene analogs showed high similarity with RGAs deposited in the GenBank (Table 2). P. glabra RGA had $71 \%$ identity (E value $8 \mathrm{e}^{-42}$ ) with putative resistance protein KNBS4 of Glycine max (GI: 13111697 ) followed by $68 \%$ identity (E value $2 \mathrm{e}^{-63}$ ) with NBS-LRR type disease resistance protein RPG1-B of $G$. max (GI: 38373621; GI: 38373623; GI: 38373625) and disease resistance protein, AAA ATPase of Medicago truncatula (GI: 92885110). The lowest E values confirm that the matches are more reliable and not due to chance. The RGAs identified in A. pavonina and C. ternatea showed $45 \%$ (E value $5 \mathrm{e}^{-25}$ ) and $42 \%$ (E value $3 \mathrm{e}^{-29}$ ) identity with NBS- type resistance protein of Gossypium barbadense (GI: 29703837). S. trilobatum RGA exhibited strong matches with the amino acid sequences of ATP binding protein of A. thaliana (GI: 30696557; Identity$52 \%$; E value $1 \mathrm{e}^{-42}$ ), T1F9.21 of A. thaliana (GI: 3056600 ; Identity- $52 \%$; E value $5 \mathrm{e}^{-42}$ ), putative disease resistance 
protein At1g61300 of A. thaliana (GI: 46395619; Identity$52 \%$; E value $5 \mathrm{e}^{-42}$ ) followed by NBS-LRR-Non-Toll resistance gene analog protein of Medicago ruthenica (GI: 19774147; Identity- 52\%; E value-5 $\mathrm{e}^{-41}$ ). The $\mathrm{E}$ value was taken in to consideration for the appropriateness of the match. The expected (E) value refers to the number of matches expected by chance alone; lower the $\mathrm{E}$ value indicates that the match is more reliable and not occurred purely due to chance (Di Gaspero and Cipriani, 2002; Totad et al. 2005).

Studies on $R$-genes and RGAs are still explorative in nature. Information on more $R$-gene sequences is necessary to delineate more structural domains, which is the basis for the search of RGAs in any crop plant (Totad et al. 2005). The diversity among the novel RGAs characterized in this study may lead to mining of $R$ - genes in other non edible legumes and wild Solanum species.

\section{REFERENCES}

AARTS, M.G.M.; HEKKERT, B.T.L.; HOLUB, E.B.; BEYNON, J.L.; STIEKEMA, W.J. and PEREIRA, A. Identification of R-gene homologous DNA fragments genetically linked to disease resistance loci in Arabidopsis thaliana. Molecular Plant- Microbe Interaction, April 1998, vol. 11, no. 4, p. 251-258.

ALTSCHUL, S.F.; MADDEN, T.L.; SCHAFFER, A.A.; ZHANG, J.; ZHANG, Z.; MILLER, W. and LIPMAN, D.J. Gapped BLAST and PSI-BLAST: a new generation of protein database search programs. Nucleic Acids Research, 1997, vol. 25, no. 17, p. 3389-3402.

BAI, J.; PENNILL, L.A.; NING, J.; LEE, S.W.; RAMALINGAM, J.; WEBB, C.A.; ZHAO, B.; SUN, Q.; NELSON, J.C.; LEACH, J.E. and HULBERT, S.H. Diversity in nucleotide binding site-leucine-rich repeat genes in cereals. Genome Research, December 2002, vol. 12 , no. 12 , p. $1871-1884$.

BALDI, P.; PATOCCHI, A.; ZINI, E.; TOLLER, C.; VELASCO, R. and KOMJANC, M. Cloning and linkage mapping of resistance gene homologues in apple. Theoretical and Applied Genetics, June 2004, vol. 109, no. 1, p. 231-239.

BENT, A.F.; KUNKEL, B.N.; DAHLBECK, D.; BROWN, K.L.; SCHMIDT, R.; GIRADAUT, J.; LEUNG, J. and STASKAWICZ, B.J. RPS2 of Arabidopsis thaliana: a leucine-rich repeat class of plant disease resistance genes. Science, 1994, vol. 265, no. 5180, p. 1856-1860.

BIRNBOIM, H.C. and DOLY, J. A rapid alkaline extraction procedure for screening recombinant plasmid DNA. Nucleic Acids Research, 1979, vol. 7, no. 6, p. 15131523.

BROTMAN, Y.; SILBERSTEI, L.; KOVALSKI, I.; PERIN, C.; DOGIMONT, C.; PIRAT, M.; KLINGER, J.;
THOMPSON, G.A. and PERL-TREVES, R. Resistance gene homologues in melon are linked to genetic loci conferring disease and pest resistance. Theoretical and Applied Genetics, 2002, vol. 104, no. 6-7, p. 1055-1063.

CANNON, S.B.; ZHU, H.; BAUMGARTEN, A.M.; SPANGLER, R.; MAY, G.; COOK, D.R. and YOUNG, N.D. Diversity, distribution, and ancient taxonomic relationships within the TIR and Non-TIR NBS-LRR resistance gene subfamilies. Journal of Molecular Evolution, 2002, vol. 54, no. 4, p. 548-562.

CHEN, X.M.; LINE, R.F. and LEUNG, H. Genome scanning for resistance-gene analogs in rice, barley, and wheat by high-resolution electrophoresis. Theoretical and Applied Genetics, 1998, vol. 97, no. 3, p. 345-355.

CLAMP, M.; CUFF, J.; SEARLE, S.M. and BARTON, G.J. The Jalview Java alignment editor. Bioinformatics, 2004, vol. 20, no. 3, p. 426-427.

COLLINS, N.C.; WEBB, C.A.; SEAH, S.; ELLIS, J.G.; HULBERT, S.H. and PRYOR, A. The isolation and mapping of disease resistance gene analogs in maize. Molecular Plant-Microbe Interaction, 1998, vol. 11, no. 10, p. $968-978$.

DENG, Z.; HUANG, S.; LING, P.; CHEN, C.; YU, C.; WEBER, C.A.; MOORE, G.A. and GMITER, JR F.G. Cloning and characterization of NBS-LRR class resistancegene candidate sequences in citrus. Theoretical and Applied Genetics, 2000, vol. 101, no. 5-6, p. 814-822.

DI GASPERO, G. and CIPRIANI, G. Resistance gene analogs are candidate markers for disease-resistance genes in grape (Vitis spp.). Theoretical and Applied Genetics, 2002, vol. 106, no. 1, p. 163-172.

DONALD, T.M.; PELLERONE, F.; ADAM-BLONDON, A.F.; BOUQUET, A.; THOMAS, M.R. and DRY, I.B. Identification of resistance gene analogs linked to a powdery mildew resistance locus in grapevine. Theoretical and Applied Genetics, March 2002, vol. 104, no. 4, p. 610618.

DOYLE, J.J. and DOYLE, J.L. Isolation of plant genomic DNA from fresh tissue. Focus, 1990, vol. 12, no. 1, p. 1315.

GENTZBITTEL, L.; MOUZEYAR, S.; BADAOUI, S.; MESTRIES, E.; VEAR, F.; DE LABROUHE, D.T. and NICOLAS, P. Cloning of molecular markers for disease resistance in sunflower, Helianthus annus L. Theoretical and Applied Genetics, 1998, vol. 96, no. 3-4, p. 519-525.

GOVINDAN, $\quad$ S.; $\quad$ VISWANATHAN, $\quad$ S.; VIJAYASEKARAN, V. and ALAGAPPAN, R. A pilot study on the clinical efficacy of Solanum xanthocarpum and Solanum trilobatum in bronchial asthma. Journal of Ethnopharmacology, 1999, vol. 66, no. 2, p. 205-210. 
GOWDA, B.S.; MILLER, J.L.; RUBIN, S.S.; SHARMA, D.R. and TIMKO, M.P. Isolation, sequence analysis, and linkage mapping of resistance-gene analogs in cowpea (Vigna unguiculata L. Walp). Euphytica, 2002, vol. 126, no. 3, p. 365-377.

GRANT, M.R.; GODIARD, L.; STRAUBE, E.; ASHFIELD, T.; LEWALD, J.; SATTLER, A.; INNES, R. and DANGL, J.L. Structure of the Arabidopsis RPMI gene enabling dual specificity disease resistance. Science, 1995, vol. 269 , no. 5225 , p. 843-846.

HAMMOND-KOSACK, K.E. and JONES, J.D.G. Plant disease resistance genes. Annual Review of Plant Physiology and Plant Molecular Biology, 1997, vol. 48, p. 575-607.

HE, C.Y.; TIAN, A.G.; ZHANG, J.S.; ZHANG, Z.Y.; GAI, J.Y. and CHEN, S.Y. Isolation and characterization of a full-length resistance gene homolog from soybean. Theoretical and Applied Genetics, 2003, vol. 106, no. 5, p. 786-793.

HINCHLIFFE, D.J.; LU, Y.; POTENZA, C.; GOPALAN, C.S.; CANTRELL, R.G. and ZHANG, J. Resistance gene analogue markers are mapped to homeologous chromosomes in cultivated tetraploid cotton. Theoretical and Applied Genetics, 2005, vol. 110, no. 6, p. 1074-1085.

HUETTEL, B.; SANTRA, D.; MUEHLBAUER, F. and KAHL, G. Resistance gene analogues of chickpea (Cicer arietinum L.): isolation, genetic mapping and association with a Fusarium resistance gene cluster. Theoretical and Applied Genetics, 2002, vol. 105, no. 2-3, p. 479-490.

ILAG, L.L.; YADAV, R.C.; HUANG, N.; RONALD, P.C. and AUSUBEL, F.M. Isolation and characterization of disease resistance gene homologues from rice cultivar IR64. Gene, 2000, vol. 255, no. 2, p. 245-255.

JEONG, S.C.; HAYES, A.J.; BIYASHEV, R.M. and SAGHAI MAROOF, M.A. Diversity and evolution of a non-TIR-NBS sequence family that clusters to a chromosomal 'hotspot' for disease resistance genes in soybean. Theoretical and Applied Genetics, 2001, vol. 103, no. 2-3, p. 406-414.

JOYEUX, A.; FORTIN, M.G.; MAYERHOFER, R. and GOOD, A.G. Genetic mapping of plant disease resistance gene homologues using a minimal Brassica napus L. population. Genome, 1999, vol. 42, no. 4, p. 735-743.

KALAMANI, A. and MICHAEL GOMEZ, S. Genetic variability in Clitoria spp. Annals of Agricultural Research, 2001, vol. 22, no. 2, p. 243-245.

KALAMANI, A. and MICHAEL GOMEZ, S. In vitro propagation studies in Clitoria spp. International Journal Mendel, 2002, vol. 19, no. 2, p. 29-30.
KALAMANI, A. and MICHAEL GOMEZ, S. Exploitation of new ornamental types in Clitoria (Clitoria spp.). International Journal Mendel, 2003, vol. 20, no. 2, p. 4142.

KALOSHIAN, I.; YAGHOOBI, J.; LIHARSKA, T.; HONTELEZ, J.; HANSON, D.; HOGAN, P.; JESSE, T.; WIJBRANDI, J.; SIMONS, G.; VOS, P.; ZABEL, P. and WILLIAMSON, V.M. Genetic and physical localization of the root-knot nematode locus $\mathrm{Mi}$ in tomato. Molecular and General Genetics, 1998, vol. 257, no. 3, p. 376-385.

KANAZIN, V.; FREDERICK, M.L. and SHOEMAKER, R.C. Resistance gene analogs are conserved and clustered in soybean. Proceedings of the National Academy of Sciences of the United States of America, 1996, vol. 93, no. 21, p. 11746-11750.

KELEMU, S.; CARDONA, C. and SEGURA, G. Antimicrobial and insecticidal protein isolated from seeds of Clitoria ternatea, a tropical forage legume. Plant Physiology and Biochemistry, 2004, vol. 42, no. 11, p.867873.

LACOCK, L.; VAN NIEKERK, C.; LOOTS, S.; DU PREEZ, F. and BOTHA, A.M. Functional and comparative analysis of expressed sequences from Diuraphis noxia infested wheat obtained utilizing the conserved Nucleotide Binding Site. African Journal of Biotechnology, 2003, vol. 2, no. 4, p. 75-81.

LANAUD, C.; RISTERUCCI, A.M.; PIERETTI, I.; N'GORAN J.A.K and FARGEAS, D. Characterisation and genetic mapping of resistance and defence gene analogs in cocoa (Theobroma cacao L.). Molecular Breeding, 2004, vol. 13 , no. 3, p. 211-227.

LAWRENCE, G.J.; FINNEGAN, E.J.; AYLIFFE, M.A. and ELLIS, J.G. The $L 6$ gene for flax rust resistance is related to the Arabidopsis bacterial resistance gene RPS2 and the tobacco viral resistance gene, N. Plant Cell, 1995, vol. 7, no. 8, p. 1195-1206.

LEE, S.Y.; SEO, J.S.; RODRIGUEZ-LANETTY, M. and LEE, D.H. Comparative analysis of superfamilies of NBSencoding disease resistance gene analogs in cultivated and wild apple species. Molecular Genetics and Genomics, 2003, vol. 269, no. 1, p. 101-108.

LEISTER, D.; BALLVORA, A.; SALAMINI, S. and GEBHARDT, C. A PCR based approach for isolating pathogen resistance genes from potato with potential for wide application in plants. Nature Genetics, 1996, vol. 14, no. 4, p. 421-429.

LOPEZ, C.E.; ACOSTA, I.F.; JARA, C.; PEDRAZA, F.; GAITÁN-SOLÍS, E.; GALLEGO, G.; BEEBE, S.; and TOHME, J. Identifying resistance gene analogs associated with resistances to different pathogens in common bean. Phytopathology, 2003, vol. 93, no. 1, p. 88-95. 
MADHAVAN, S. and BALU, S. Ethnobotanical studies on Solanum trilobatum Linn: an Indian drug plant. Journal of Economic and Taxonomic Botany, 1999, vol. 23, no. 1, p. 43-46.

MAGO, R.; NAIR, S. and MOHAN, M. Resistance gene analogues from rice: cloning, sequencing and mapping. Theoretical and Applied Genetics, 1999, vol. 99, no. 1-2, p. 50-57.

MAS, J.G.; VAN LEEUWEN, H.; MONFORT, A.; DE VICENTE, M.C.; PUIGDOME'NECH, P. and ARU'S, P. Cloning and mapping of resistance gene homologues in melon. Plant Science, 2001, vol. 161, no. 1, p. 165-172.

MEYERS, B.C.; DICKERMAN, A.W.; MICHELMORE, R.W.; SIVARAMAKRISHNAN, S.; SOBRAL, B.W. and YOUNG, N.D. Plant disease resistance genes encode members of an ancient and diverse protein family within the nucleotide-binding superfamily. Plant Journal, 1999, vol. 20 , no. 3 , p. 317-332.

MICHAEL GOMEZ, S. and KALAMANI, A. Butterfly pea (Clitoria ternatea): A nutritive multipurpose forage legume for the tropics - An over view. Pakistan Journal of Nutrition, 2003, vol. 2, no. 6, p. 374-379.

MILLIGAN, S.B.; BODEAU, J.; YAGHOOBI, J.; KALOSHIAN, I.; ZABEL, P. and WILLIAMSON, V.A. The root knot nematode resistance gene $\mathrm{Mi}$ from tomato is a member of the leucine zipper, nucleotide binding, leucine-rich repeat family of plant genes. Plant Cell, 1998, vol. 10 , no. 8, p. 1307-1319.

MINDRINOS, M.; KATAGIRI, F.; YU, G.L. and AUSUBEL, F.M. The Arabidopsis thaliana disease resistance gene RPS2 encodes a protein containing a nucleotide-binding site and leucine-rich repeats. Cell, 1994, vol. 78, no. 6, p. 1089-1099.

MOHANAN, P.V. and DEVI, K.S. Cytotoxic potential of the preparation from Solanum trilobatum and the effect of sobatum on tumor reduction in mice. Cancer Letter, 1996, vol. 110 , no. 1-2, p. 71-76.

MOHANAN, P.V. and DEVI, K.S. Effect of sobatum on tumor development and chemically induced carcinogenesis. Cancer Letter, 1997, vol. 112, no. 2, p. 219-223.

NOIR, S.; COMBES, M.C.; ANTHONY, F. and LASHERMES, P. Origin, diversity and evolution of NBStype disease-resistance gene homologues in coffee trees (Coffea L.). Molecular Genetics and Genomics, 2001, vol. 265, no. 4, p. 654-662.

PAN, Q.; WENDEL, J. and FLUHR, R. Divergent evolution of plant NBS-LRR resistance gene homologues in dicot and cereal genomes. Journal of Molecular Evolution, 2000, vol. 50, no. 3, p. 203-213.
PEÑUELA, S.; DANESH, D. and YOUNG, N.D. Targeted isolation, sequence analysis, and physical mapping of nonTIR NBS-LRR genes in soybean. Theoretical and Applied Genetics, 2002, vol. 104, no. 2-3, p. 261-272.

PLOCIK, A.; LAYDEN, J. and KESSELI, R. Comparative analysis of NBS domain sequences of NBS-LRR disease resistance genes from sunflower, lettuce and chicory. Molecular Phylogenetics and Evolution, 2004, vol. 31, no. 1, p. 153-163.

RAJKUMAR, S. and JEBANESAN, A. Oviposition deterrent and skin repellent activities of Solanum trilobatum leaf extract against the malarial vector Anopheles stephensi. Journal of Insect Science, 2005, vol. 5, p. 15.

RAMASUBRAMANIAN, T. and REGUPATHY, A. Magnitude and mechanism of insecticide resistance in Helicoverpa armigera populations of Tamil Nadu, India. Asian Journal of Plant Sciences, 2004, vol. 3, no. 1, p. 94100.

RIVKIN, M.I.; VALLEJOS, C.E. and MCCLEAN, P.E. Disease-resistance related sequences in common bean. Genome, 1999, vol. 42, no. 1, p. 41-47.

SANTOS, I.S.; CUNHA, M.D.; MACHADO, O.L.T. and GOMES, V.M. A chitinase from Adenanthera pavonina L. seeds: purification, characterisation and immunolocalisation. Plant Science, 2004, vol. 167, no. 6, p. 1203-1210.

SARASTE, M.; SIBBAD, P.R. and WITTINGHOFER, A. The P-loop-a common motif in ATP- and GTP-binding proteins. Trends in Biochemical Sciences, 1990, vol. 15, no. 11, p. 430-434.

SEAH, S.; SIVASITHAMPARAM, K.; KARAKOUSIS, A. and LAGUDAH, E.S. Cloning and characterization of a family of disease resistance gene analogs from wheat and barley. Theoretical and Applied Genetics, 1998, vol. 97, no. 5-6, p. 937-945.

SHEN, K.A.; MEYERS, B.C.; ISLAM-FARIDI, M.N.; CHIN, D.; STELLY, D.M. and MICHELMORE, R.W. Resistance gene candidates identified by PCR with degenerate oligonucleotide primers map to clusters of resistance genes in lettuce. Molecular Plant-Microbe Interaction, 1998, vol. 11, no. 8, p. 815-823.

TATUSOVA, T.A. and MADDEN, T.L. Blast 2 sequences - a new tool for comparing protein and nucleotide sequences. FEMS Microbiology Letters, 1999, vol. 174, no. 2, p. 247-250.

THOMPSON, J.D.; GIBSON, T.J.; PLEWNIAK, F.; JEANMOUGIN, F. and HIGGINS, D.G. The ClustalX windows interface: Flexible strategies for multiple 
sequence alignment aided by quality analysis tools. Nucleic Acids Research, 1997, vol. 25, no. 24, p. 4876-4882.

TIMMERMAN-VAUGHAN, G.M.; FREW, T.J. and WEEDEN, N.F. Characterization and linkage mapping of R-gene analogous DNA sequences in pea (Pisum sativum L.). Theoretical and Applied Genetics, 2000, vol. 101, no. 1-2, p. 241-247.

TOTAD, A.S.; FAKRUDIN, B. and KURUVINASHETTI, M.S. Isolation and characterization of resistance gene analogs (RGAs) from sorghum (Sorghum bicolor L. Moench). Euphytica, 2005, vol. 143, no. 1-2, p.179-188.

TRAUT, T.W. The functions and consensus motifs of nine types of peptide segments that form different types of nucleotide binding-sites. European Journal of Biochemistry, 1994, vol. 222, no. 1, p. 9-19.

WALKER, J.E.; SARASTE, M.; RUNSWICK, M.J. and GAY, N.J. Distantly related genes in the alpha and beta subunits of ATP synthetase, myosin, kinases and other ATP-requiring enzymes and a common nucleotide-binding fold. EMBO Journal, 1982, vol. 1, no. 8, p. 945-951.

WENKAI, X.; MINGLIANG, X.; JIUREN, Z.; FENGGE, W.; JIANSHENG, L. and JINGRUI, D. Genome-wide isolation of resistance gene analogs in maize (Zea mays L.). Theoretical and Applied Genetics, 2006, vol. 113, no. 1, p. 63-72.

WHITHAM, S.; DINESH-KUMAR, S.P.; CHOI, D.; HEHL, R.; CORR, C. and BAKER, B. The product of the tobacco mosaic virus resistance gene $N$ : similarity to toll and the interleukin-1 receptor. Cell, 1994, vol. 78, no. 6, p. $1101-1115$.

YOSHIMURA, S.; YAMANOUCHI, U.; KATAYOSE, Y.; TOKI, S.; WANG, Z.X.; KONO, I.; KURATA, N.; YANO, M.; IWATA, N. and SASAKI, T. Expression of Xa1 a bacterial blight-resistance gene in rice is induced by bacterial inoculation. Proceedings of the National Academy of Sciences of the United States of America, 1998, vol. 95, no. 4, p. 1663-1668.

YU, Y.G.; BUSS, G.R. and SAGHAI MAROOF, M.A. Isolation of a super family of candidate disease-resistance genes in soybean based on a conserved nucleotide-binding site. Proceedings of the National Academy of Sciences of the United States of America, 1996, vol. 93, no. 21, p. 11751-11756.

ZHANG, L.P.; KHAN, A.; NIÑO-LIU, D. and FOOLAD, M.R. A molecular linkage map of tomato displaying chromosomal locations of resistance gene analogs based on a Lycopersicon esculentum x Lycopersicon hirsutum cross. Genome, 2002, vol. 45, no. 1, p. 133-146. 


\section{APPENDIX FIGURES}

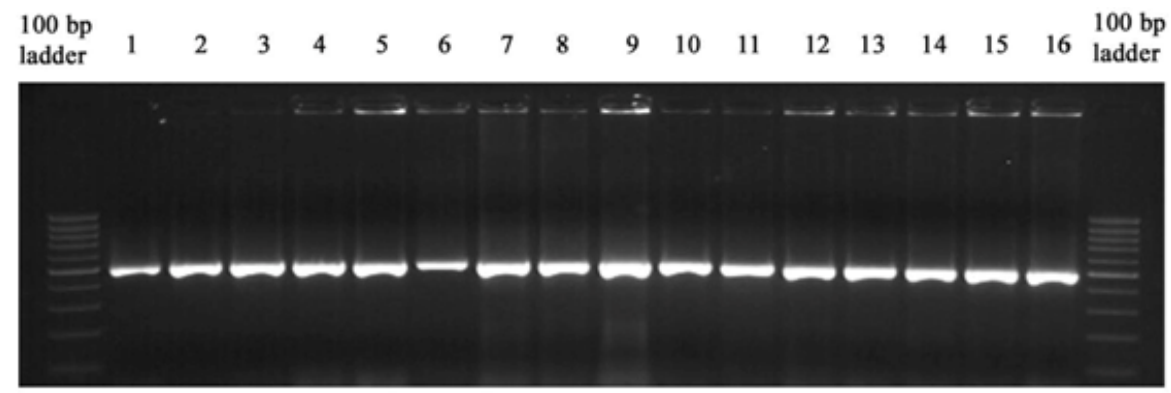

$500 \mathrm{bp}$

Figure 1. PCR amplification of targeted PCR fragment in transformed colonies of Escherichia coli. Lanes 1-4, 5-8, 9-12 and 1316 represent individual colonies from Adenanthea pavonia, Clitoria ternatea, Pongamia glabra, and Solanum trilobatum, respectively. The "100 bp ladder" (Fermentas Life Sciences) was used as size markers.

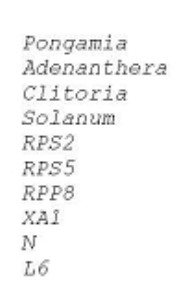

Pongamia Adenanthera Clitoria Solanim RPS2 RPS5 RPP8 XAI $N$ L 6

Pongamia
Adenanthera
Clitoria
Solanum
RPS2
RPS5
RPP8
XAI
N
L6

Pongamia Adenanthera Clitoria SoIanum RPS 2 RPS 5 RPP 8 $X A 1$ $N$
$L 6$
Kinase $1 a$

GGVGKTTLAOYVYNDP-RMEMBEYKFGIKAIVVSVSDDF-----DVYKVTRAILEAIT-KS 53 GGVGKTT IAKBVAKK---LKGE-KMIFKRVIMAVVSNDM-----NIENI-SQIAEMLGMKL 50 GGVGKTTIAKBVAVK---VKDE-RMS ENVIMAIVSDDV-----NLEKVQGOIAEMLGMKL 51 GGVGKTT LMKKVNNE---FARS-HDEDLVIWVVVSKDR-----NVDKIVDDICKGAHIFA 51 GGVGKTTLMQS INNE---LITKGHQYDVLIWVQMSREE-----GECTIQQAVGARLGLS- 51 GGVGKTT LLTQINNK---FSKLGGGFDVVIWVVVSKNA-----TVHKIQKS IGEKLGLVG 52 GGIGKTTLARQVFHH----DLVRRHFDGFANVCVSQQF-----TQKHVWQRI LQBLQPHD 51 GGIGKTTLAQLVCKD----LVIKSQENVKIWVYVSDKE-----DVVKI TRQI LDHVSNQS 51 GGVGKTT IARAIFDTLIGRIMDSSYQFDGACFLKDIKEN--KRGMHSLQNALLSELLREKA 58 GGIGKTTTAKAVYN----KISS--CFDCCCF IDNIRETQEKDGVVVLQKKLVSEILRIDS 54 $* *: * * * * \quad:$

:

Kinase 2

TVHSRDLEIVQG-RLKDKLKGKR-FLLVLDDVWNEKRBBWEALQTPLNYG---------A 102 DEKTESIRAS---HLCBRLKQBKNLLITLDDLVEKLDLGKVGMSP IHDGN-----YNKKN 102 DEKTESIRAS---RLCBRLKOEKNLLIILDVLREKLDLGKVGMSF IDDGK-----YNKNS 103 MNES IDDKTR---EIYNVLKHKK-FVLLLDD IVEGLDIDS IGVP P PNE------_-_--R 96 WDEKETGENR-ALKIYRALRQKR-FLLLLDDVWEEIDLBKTGVPRPDR------------E 98 KWWDEKNKNQRALDIHNVLRRKK-FVLLLDD IWEKVELKVIGVPYPSG----------E 100 GDILQMDEYALQRKLEQLLEAGK-YLVVLDDVWKKEDWDVIKAVEPRK------------ 98 HEGI SNLDTLCQ-DLEEQMKSKK-FLIVLDDVWE I RTDDWIKKLLAPLRPNDQVNSSQEEA 109 N---YNNEEDGKHOMASRLRSKK-VLIVLDDIDNKDHYLEYLAGDLD----------WFG 104 GSVGFNNDSGGRKTIKBRVSRFK-ILVVLDDVDEKFKF BDMLGSPKD----------FIS 103

$$
:::::: * *: \text { : : }
$$

Kinase $3 a$

QGSKILVTTR-NMEVASTMR-SDKIYSLKQLQEEQCWKVFAKHAFN---VENFQLNPELK 157 BGCKILLT SRNEKLLSDQMK-CBRNIKVGVLSBKEAINELFKRISEL---STNSN-SLDLM 157 KGWKI LLT SRNEKLLSDOMK-CGRNIKVGLLSDKEAWBLLFKRIAEL---PIDS I-SPDEI 158 NKSKVLFTTR-LESVCDQMQ-AKK-FEVKCLTKBEAFDLFCVKVGE---BTINA-EPTIR 149 NKCKVMETTR-SIALCNNMG-AEYKLRVEFLEKKHAWELFCSKVWR---KDLLE-SSSIR 152 NGCKVAETTH-SKEVCGRMG-VDNPMEISCLDTGNAINDLLKKKVGE---NTLGS-HPDIP 154 RGWKMLLTSR-NEGVGIHADPTCLTFRASILNPEESWKLCERIVFPRRDETEVRLDEEME 157 TGMMI ILTTR-IQS IAKS LG-TVQS I KLEALKDDDIWS LFKVHAFG---NDKHDSSPGLQ 164 NGSRI I ITTRDK---HLTEKNDI YVVTALPDHES TOLFKOHAFG--KEVPN--ENEE 155 *: :

\section{$H D$}

NIGILIVDKCKGLPLAW 174 PVAIBIAQKCEGLPLAW 174 SVAIBIVQKCEGLPLAW 175 BLARELIQECKGLPLA/ 166 RLAEI IVSKCGGLPLAL 169 QLARKVSEKCCGLPLAL 171 AMGKEMVTHCGGLPLAV 174 VLGKQIASELKGNPLAA 181 KLSLEVVNYAKGLPLAL KLSLEINIAGLPLAL 17 TLANDVVDTTAGLPLTL 17
$: \quad: \quad * * *:$

Figure 2. Multiple alignment of deduced amino acid sequences of RGAs with known NBS-LRR class $R$-genes $\boldsymbol{N}$ (accession no. U15605), RPS2 (accession no. U14158), RPS5 (accession no. AF074916), RPP8 (accession no. AF089710), XA1 (accession no. AB002266)and L6 (accession no. U27081) using CLUSTALW. 


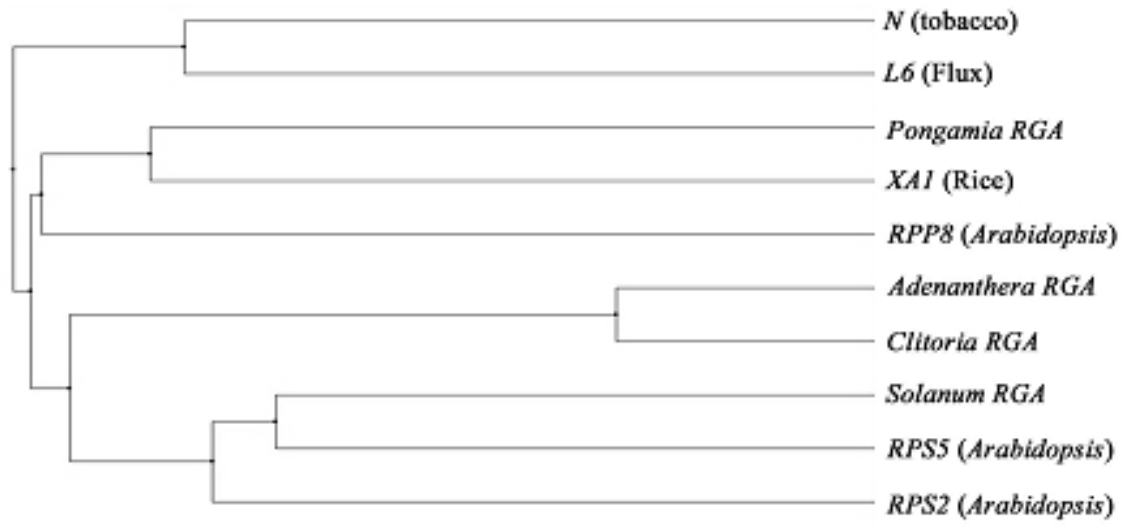

Figure 3. Average distance tree using BLOSUM62 showing relationship of RGAs with characterized NBS-LRR class of $R$ genes.

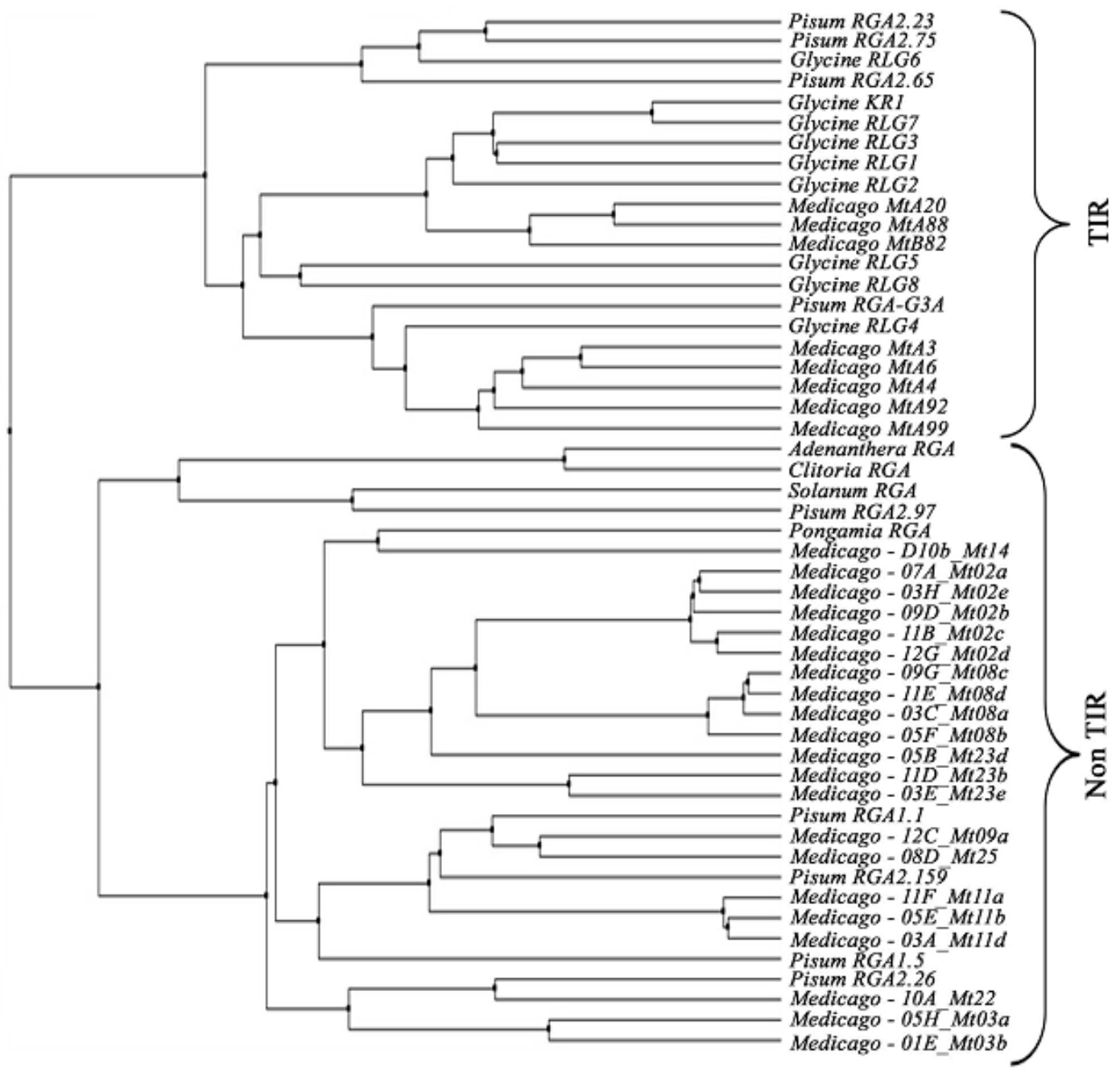

Figure 4. Average distance tree using BLOSUM62 showing relationship of RGAs with RGAs isolated from model legumes, Pisum sativum (Timmerman-Vaughan et al. 2000), Glycine max (Kanazin et al. 1996) and Medicago truncatula (Cannon et al. 2002). 